\title{
Conservative Social Politics in Austria, 1880-1890
}

\author{
Margarete Grandner \\ University of Vienna \\ July 1994 \\ Working Paper 94-2
}

(C) 1997 by the Center for Austrian Studies. Permission to reproduce must generally be obtained from the Center for Austrian Studies. Copying is permitted in accordance with the fair use guidelines of the US Copyright Act of 1976. The the Center for Austrian Studies permits the following additional educational uses without permission or payment of fees: academic libraries may place copies of the Center's Working Papers on reserve (in multiple photocopied or electronically retrievable form) for students enrolled in specific courses: teachers may reproduce or have reproduced multiple copies (in photocopied or electronic form) for students in their courses. Those wishing to reproduce Center for Austrian Studies Working Papers for any other purpose (general distribution, advertising or promotion, creating new collective works, resale, etc.) must obtain permission from the Center.

In the decade from 1880 to 1890, a series of social laws were enacted in Austria comprising measures such as the limitation of the length of the workday in factories and mines, restrictions on the employment of women and young people under certain circumstances, and the introduction of accident and sickness insurance. ${ }^{(1)}$ This legislation followed both the German example in embarking upon social insurance and the "Swiss model" of extensive protective legislation.

Limitation of working hours in Switzerland can be traced back to the early nineteenth century when, in the canton of Glarus, a highly industrialized textile area in the east of the country, work in spinning mills was generally forbidden during the night for climatic reasons. In the decades to come, technical conditions dramatically changed, reducing the danger of fire caused by the illumination of workshops, so employers finally in 1847 were allowed to reintroduce night shifts. In exchange, however, the Council of Glarus limited working hours generally. Finally, in 1874, the Swiss electorate voted in favor of a revision of the Swiss constitution, which among other things empowered the central government to interfere with labor conditions nationwide. The Factory Act, which followed in 1877, introduced a maximum workday of eleven hours in Swiss industry and ten hours on Saturdays and days preceding holidays for both women and men. ${ }^{(2)}$ In addition the law forbade female work during nights and on Sundays "under any conditions" and the employment of women for eight weeks around the date of delivery; it also included several protective measures for children and young persons. Finally, the law introduced factory inspection. The Factory Act itself was accepted by a popular referendum, though by a very narrow margin (51 percent). ${ }^{(3)}$ The exceptional feature of 
the Swiss Factory Act contrasting it to earlier English or later French legislation is its determined inclusion of male adults as the group of workers to whom the notion of free agents was usually most persistently applied.

Germany pioneered in the field of social insurance, and Bismarck's motives for this kind of social policy have drawn broad attention. Although sickness, accident, and old age (invalidity) insurance introduced in 1883, 1884 and 1889 respectively certainly aimed at containing socialism and at appeasing the industrial workforce and thus at the preservation of the political status quo, the institutions themselves were major social innovations. Compulsory membership in the funds, financed exclusively or mainly by contributions from the workers and their employers, and direct state involvement, as well as central state supervision, marked decisive steps away from the traditional poor relief systems and constructed a new relationship between the individual workers, the employers, and the state.

There are important differences between the Swiss and German ways of action. It is well known that Bismarck himself strictly opposed and wrecked plans suggested by his councilors regarding hours legislation. ${ }^{(4)}$ Germany did not restrict working hours for adult men until after World War I. Switzerland, on the other hand, was rather slow in approaching social insurance. In 1900, only 30 percent of the voters participating in a referendum voted in favor of a bill that had been drawn up according to the German model and enjoyed the support of all Parliamentary parties. A law of 1912 finally did introduce compulsory and contributory accident insurance, but sickness insurance was shaped on strictly voluntary terms, and as a national, not a workmen's, scheme. Even so, this law only received 54 percent of the vote in a referendum. ${ }^{(5)}$

Both countries, it may be argued, would have been able to afford both kinds of social policies. Not comparable with regard to size, of course, the German and the Swiss economies were well developed at the end of the nineteenth century. Germany was on her way to become a serious competitor to England in many fields, especially the "new" technologically advanced industries; Switzerland as an extremely small and exposed economy found its niche by specializing in high quality products. As a consequence of its very particular economic situation, however, Switzerland had a highly developed insurance business sector, which (as in the American case) explains a good deal of its cautious activity in the field of social insurance.

Both countries started as relatively weak central states when they embarked on social politics, and both employed this field of action to strengthen central power. The new German Empire of 1871 had few powers concerning domestic politics and was dependent on the finances of the federal lands. Social insurance legislation by the Reichstag has its place within the framework of Bismarck's "second founding" of the Empire. In the war of 1846 Switzerland overcame the secession of several cantons, but the process of transforming a loose federation of states into a federal state dragged on for nearly three decades. The ability of the central Parliament to enact factory laws then was part and parcel of the constitutional revision in 1874. 
German social insurance strengthened the central state most visibly in the creation and in the development of the Imperial Insurance Office in an autocratic political system that invited direct state involvement; however, political structures and performance in Switzerland remained liberal and democratic. The authorization of the central state to enact protective laws did not automatically include social insurance. Although, in the wake of German social insurance, the Swiss electorate voted by a large majority (75 percent) in 1890 for a constitutional amendment to include social insurance in the central agenda, they remained highly suspicious of a service state with its innate interventionist powers. ${ }^{(6)}$

On the other hand, a liberal standpoint as it was brought forward by Bismarck against factory legislation did not prevent Switzerland from introducing a law which even interfered with male adults' freedom of contract. Swiss factory legislation in fact followed and outstripped that of England, where the Liberal Party and liberal intellectuals like John Stuart Mill endorsed factory legislation (for women and children) after the Tories had started on this path in the 1830s. In a detached manner, by the rule of the law, the state constrained the choice of working conditions by both workers and employers. Such a policy was less feasible in Germany with its polarized political climate. It was the fact that Social Democracy in Germany pushed for protective legislation, not for social insurance, in the 1860s and 1870s far more than his liberal convictions, that prompted Bismarck to turn it down. ${ }^{(7)}$

The political regime that introduced both protective labor legislation and social insurance in Austria, the so-called "Iron Ring," may best be characterized by the "anti-sentiments" that made it stick together and retain power for more than a decade despite otherwise severe cleavages: the men in Count Eduard Taaffe's government, and especially the new majority in Parliament, endorsed anti-liberalism, anti-capitalism, anti-socialism, and anticentralism. ${ }^{(8)}$ They can be seen as reacting to: secularization, the cultural and political hegemony of German Austrians over the Slavic peoples, economic laissez faire politics as promoted by the Liberals in the late 1860s and the 1870s, the social distortions caused by the industrialization and aggravated by the Depression after 1873, and the threat of a growing Marxist labor movement. Expressed in positive terms, the ideology of the Iron Ring could be labeled as a comprehensive backward-looking conservatism with a distinct touch of catholicism.

While political leaders in Austria thus shared some important convictions with Bismarck's regime in contemporary Germany, especially anti-Marxism, ${ }^{(9)}$ they lacked the Imperial Chancellor's devotion to big industry and replaced it by an apotheosis of preindustrial crafts. Compared to both Germany and Switzerland, Austria was a strong central state in structural terms as it emerged from the founding of the dual Habsburg monarchy in 1867. Within the Austrian half of the Empire (and also within Hungary) liberal leaders had managed to preserve much of the centralist heritage of the absolutist regime of the $1850 \mathrm{~s} . \stackrel{(10)}{ }$ Although federalism, as a cement of the Iron Ring, proved too weak to overcome the increasingly problematic centralistic structure of Cisleithania, $\stackrel{(11)}{2}$ it decisively impaired strong central state practice. 
Austria had been a semi-constitutional monarchy since 1861/1867; the overwhelming power resided with the Emperor (Franz Joseph) and the rest of the government was dependent upon him. The franchise for the House of Deputies (Abgeordnetenhaus) had both property and class restrictions, which, of course, excluded low income groups and favored large landed property and an urban business elite. A reform of suffrage in 1882 gave the vote to the so-called five-guilder-men, strengthening the position of groups who, for the most part, experienced industrialization as a threat to their social and economic position. Peasants and the working classes were enfranchised on the central state level only in 1896, but suffrage remained strongly unequal until 1907. Adequate representation of the interests of the population was impossible in such a system, which in turn fostered the emergence of mass grass-roots political movements since the $1880 \mathrm{~s} .{ }^{(12)}$ There were no provisions at all for "direct democracy" as laid down in the Swiss revised constitution of 1877.

From the economic point of view, Austria appears to have been far less prepared than her western and northern neighbors to fully engage in social politics. Altogether, 55.6 percent of the population in 1880 still belonged to the agricultural sector, only 20.5 percent to the industrial sector (as compared to 43.5 percent and 32.9 percent in Germany; 37.4 percent and 40.2 percent in Switzerland). The picture did not change decisively in the following decades. The census turnout of 1910 even indicated a growth of the agricultural sector (56.9 percent), ${ }^{(13)}$ and considering the previously low level only a small expansion of the industrial one (23.5 percent). German numbers in 1907 were 35.2 percent for agriculture, 39.0 percent for industry; in 1910 Switzerland had 26.8 percent agricultural and 44.2 percent industrial population. While it is true that Austria had several islands of industrial activity primarily Lower Austria around Vienna, northern and northwestern Bohemia, the Brünn (Brno) area, and Vorarlbergthe unevenness of development was not an argument for centralized social policy because these programs increased wage costs for fledgling, labor-intensive production by the same amount as for well established, more productive enterprises.

Why, then, would Austria's political leaders turn to social politics to such an extent? Why were they prepared to "copy" both German and Swiss legislation? Obviously, there were several good reasons to follow Bismarck's social insurance legislation. Since 1879, Austria had been allied to Germany (Zweibund). The political establishment in both countries considered the fight against socialism as a common task, especially because the Austrian and German social democratic movements were closely connected. Conservatism and autocracy were outstanding features of both political systems, and Bismarck-Germany enjoyed admiration in Austria for its economic and military achievements. Nevertheless, social insurance in Austria was built on slightly different premises from those in Germany and thus had different consequences.

The more interesting question for the moment is why Austrian politicians were so attracted to protective labor legislation. Switzerland did not provide the kind of model that Austria would have wanted to emulate thoroughly. The Swiss Factory Act served as a model in the technical sense only, although a member of the Taaffe government in 1883 
considered the legislation of the Swiss republic as the minimum to which the monarchy should aspire. ${ }^{(14)}$ But the concept that may have informed the unknown minister's statement, Lorenz von Stein's "soziales Koenigtum," certainly played a part in the Austrian conservatives' thinking. Regulation as stabilization not as development or progress fitted into their look back to pre-industrial conditions.

There were other, more tangible, reasons for the Iron Ring to become active in the field of labor protection. Industrialization in Austria during the first half of the nineteenth century took place in "pockets" of a still existing, overarching traditional society. The Austrian Civil Code of 1811 had removed traditional protective and paternalistic patterns of economic organization and had announced individual economic liberty, even for women, in an effort to create more favorable conditions for economic development, but it was applicable only where traditional regulation was lacking, that is, in the still small number of factories. There were, however, virtually no regulations. ${ }^{(15)}$

Whether the conditions of industrial labor escaped the authorities' notice or whether they consciously overlooked them is hard to decide. In any case, when state intervention did occur it clung to the traditional ways of treating dependent labor. Thus Imperial Decrees (Hofkanzleidekrete) and legislation up to the 1880s envisaged factory owners paying their workers' hospital costs. ${ }^{(16)}$ This example seems to belong to the prehistory of social insurance rather than to that of factory legislation, but it not only highlights a common root of both policies, it reflects the government view that industrial workers just like domestic servants belonged to the household of their employer. Obviously, such regulations were of little value when at the same time the employer was entitled to terminate the labor contract whenever he wanted.

At the end of the neoabsolutistic era, in 1859, a Trade Code was introduced in Austria. Being the decisive step towards centralization of economic and social legislation, this law ultimately replaced the still-existing local trade regulations and made the Civil Code

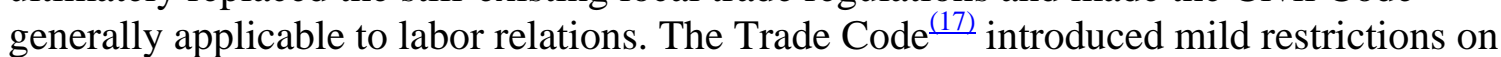
child labor for educational and moral reasons, summing up only haphazard regional starts in this direction before. $\stackrel{(18)}{ }$ Protection for adult workers was extremely scarce and simply repeated preindustrial customs. The work regulations of factories, e.g., had to include data "about the various classes of the workforce (Personal) and their tasks in particular, about the tasks assigned to women and children with regard to their physical strength and to obligatory school attendance of the latter." ${ }^{(19)}$ In default of further measures, protection for women was reduced to the possibility for the authorities to survey whether employers complied with their opinion of appropriate female work. With mechanization gaining ground, this regulation was of no practical value. ${ }^{(20)}$

The Trade Code did away with guild regulations but created trade associations (Genossenschaften) whose major object was to establish sickness funds; beyond that, the law wanted to encourage industrial entrepreneurs to found separate funds for their factories. As later development shows, neither the trade associations nor factory owners followed the advice which still echoed inadequate paternalistic organizational views in a satisfying measure. Even the truck system was forbidden only in an ambiguous manner. 
Finally, law makers in 1859 abstained from introducing factory inspection, which anyway would have had little to rely on but (middle and upper class) opinions about safety, health protection, and decency.

Things changed when by the mid-1860s economic and political liberalism became predominant forces. Economic liberalism was in a comfortable position vis-à-vis labor, given the legal situation in Austria, but a considerable and influential group among Liberal politicians felt deeply worried about the "social question," which did not stop at Bodenbach (as a proverbial statement ascribed to the Minister of the Interior, Karl von Giskra, claimed). ${ }^{(22)}$ In their effort to cope with the menace of unrest, pauperization, and degeneration, these Liberal politicians were most of all influenced by the English experience and response to industrialization. In a report about his investigations of English factory legislation, Ernst von Plener demonstrated great sympathy for a legal restriction of working hours claiming that "a well-intentioned and moderate activity of the state in favor of the laboring class does not in itself include the germ of socialism, but it is qualified for infusing into the working class an interest in the existence and preservation of today's societal order and for obviating the dangers of social revolution."

Alerted by workers' demands and motions presented by the very few social reformers in Parliament, the Liberal governments and Liberal politicians in Parliament mentioned above discussed factory legislation from 1868 until 1879. Debates focussed on restricting hours, and to a minor extent night work, for women. ${ }^{(24)}$ All groups among Austrian liberals abhorred the idea of interfering with the individual freedom of male adults, but those who wished to restrict hours for women only were also confronted with fierce

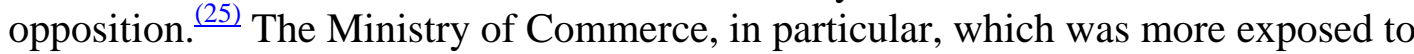
industrialists' lobbies than the Parliamentary leaders were, successfully fought back all attempts to enact protective measures for women alone, or even for girls below 21 . With only temporary wavering, the Ministry stuck to the conviction expressed in 1869 that "adult women doubtlessly [have] the same entitlement to dispose freely of their capacity for work as male workers." ${ }^{(26)}$ Backed by the legal status quo, Austrian liberals proved unable to turn towards social politics in response to the economic Depression.

"Social Reform" became the domain of Catholic conservatives like Prince Aloys Liechtenstein, Baron Karl von Vogelsang, and Count Egbert Belcredi. They were even more horrified than liberal reformers by the actual living and working conditions of the industrial population, which a sensational report published by Vogelsang's journal in 1880 had disclosed. ${ }^{(27)}$ Catholic conservatives considered state intervention a necessity. What is more important, however, is that in their ideology the "workers' question" clearly continued to be only one component of a broader "social question." Labor protection and social insurance were appendages, and indeed instruments, of the primary effort to restrengthen preindustrial forms of production. ${ }^{(28)}$ The subordinated status of labor politics in their view made it easier to proceed in an eclectic way, to choose this and that from the assortment of foreign legislation, provided the measures suited the regime's basic ideological goals. 
When the Taaffe government replaced the Liberals in 1879, factory legislation still stood where it had been in 1859; the then-intended "protective measures" had become completely worthless. In addition, the Iron Ring inherited an extensive, though hitherto fruitless, discussion about factory legislation that had focussed on special protection for female workers. Catholic politicians themselves were very sympathetic to the concept of sex-specific legislation because of their special appreciation of family values. ${ }^{(29)}$ It also seems that it would have been easy for them to win over the House of Deputies for such a proposal at the beginning of the 1880s when the Liberal Party (the "Vereinigte Linke") and the newly founded German National Party finally, in response to the new political situation, decided in favor of special protection for women. $\frac{(30)}{2}$ Nevertheless, the negotiations within the government in 1879/1880 merely repeated the pros and cons of the debates in the 1870s, pointing at the new regime's considerable undecidedness as to what to do with industrial labor.

The Iron Ring consequently resolved to postpone labor legislation. They considered it more essential to secure protection for small enterprise first; in March 1883, a major amendment to the Trade Code restricted access to a range of crafts and trades and enforced obligatory membership in the trade associations. Again, the main targets of this last regulation were the paternalistically organized sickness funds; the Parliamentary majority strictly opposed granting workers an appropriate share in their administration. $\underline{(31)}$

The next step, a very notable one into the field of labor protection, followed soon. On June 17, 1883 the emperor signed a bill introducing factory inspectors for all businesses after both Houses of Parliament had agreed upon the matter nearly without a dissenting voice. $\stackrel{(32)}{ }$ It comes as no surprise that the Parliamentary opposition consented to the introduction of factory inspection. All bills for factory legislation produced during the time of liberal rule had included such an institution, although many employers seem to have preferred a more corporative, less state-centered system. ${ }^{(33)}$ It is more surprising that there was not more support for excluding small enterprise from inspection. At the same time, the inspection of the huge number of small and tiny establishments could be merely symbolic. ${ }^{(34)}$ The main concern of the Iron Ring in the case of factory inspection seems to have been to introduce a central state agency, which would be less exposed to employers' influence than the existing local trade authorities. Although this certainly was no federalistic measure in shape, German-minded Liberals in Parliament nevertheless feared that the government would use it to exert pressure upon the large number of German factory owners in areas of mixed population. $\stackrel{(35)}{\longrightarrow}$ On the other hand, factory inspection was established before it was clear what the new civil servants would have to inspect. ${ }^{(36)}$ Partly as a consequence, their executive powers were narrowly limited, which soothed much of the apprehension entertained by both industrialists and small businessmen. ${ }^{(37)}$

Labor protection proper finally was enacted in 1885 and was based on a draft that distinctly differed from its predecessors in the 1870s. In 1883, Count Egbert Belcredi had taken the still-wavering government and Parliament by surprise when he presented a proposal that combined and in some respects overshot the protective measures then on the law books of the European states. Belcredi's draft generally prohibited employing children below 14, restricted hours to sixty per week (that is, ten hours per day) for men 
and women above 16, and to six hours per day for boys and girls aged 14-16 working in factories, prohibited night work for those under 18 and for women in enterprises of any size, and prohibited employing women for six weeks after delivery. ${ }^{(38)}$

The strikingly calm and composed reception of this proposal and the way it was modified in the ensuing negotiations suggest that Belcredi's thrust had been a well-calculated point of departure for bargaining. The first item subject to modification was the "normal workday" for all workers. As soon as negotiations began conservative leaders restructured the discussion by talking about factories and small businesses separately; thus they paved the way to exclude small businesses from Belcredi's labor protection. ${ }^{(39)}$ Through this tactic, the Iron Ring not only scored in the eyes of their own clientele but also soothed Liberal M.P.s with small business backgrounds and the Minister of Commerce. In addition, or rather in exchange, the Iron Ring was prepared to raise maximum hours per day to eleven in factories and to provide for easy access to overtime work. As in the case of mines, where hours had been generally restricted to ten in 1884, this regulation was not in conflict with the status quo because breaks, or time of descent, were not included. $\stackrel{(40)}{\longrightarrow}$ Liberals in Parliament and industrial employers finally acquiesced to it although, of course, they continued to oppose restrictions on adult men's working hours on principle. $\stackrel{(41)}{ }$

By the same means, women's night work was forbidden in factories only, and with ample possibilities for exceptions. The age when children were allowed to start regular wagework in smaller enterprises was lowered to twelve years, and only for those between age 12 and 14 were hours limited to eight. The prohibition of night work for young persons below 16, however, was valid in small businesses, as was the "maternity leave," which the Iron Ring readily agreed to abridge to four weeks "with regard to the conditions of business and actual practice."

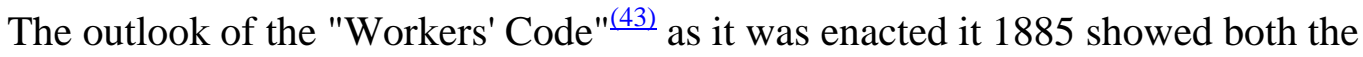
convictions of its promoters and the constraints forced upon them by economic and political considerations. By restricting protective legislation mainly to factories laws which could not, as in Switzerland, be annulled by regional regulation small business enjoyed competitive advantages vis-à-vis industry at the workers' expense. Labor protection in factories, on the other hand, was quite extensive without really changing the status quo and could serve as a signal towards the most threatening and growing component of labor, the industrial workforce. The remnants of special protection for women and children were reduced to a minimum, compared to legislation in Western Europe and even Germany as far as young people were concerned. The only exception to this might be seen in the comprehensive prohibition against employing new mothers, which suggests that motives of population politics weighed heavier than Catholic family values.

Labor protection at the workplace preceded social insurance in Austria, as it did in all of the more industrialized, Western European countries. Most of these Western European countries (and several US states) were inspired by the German example to introduce or at 
least to make attempts at introducing social insurance. This holds true in the Austrian case also: the introduction of both labor protection and social insurance was not preconceived from the beginning of conservative rule. ${ }^{(44)}$ Characteristically, trade and factory legislation during the first half of the 1880s still tried to tackle the problems of temporary incapacity to work through the employer's traditional paternalistic care for his employees. Demands raised then by Liberal politicians and by employers for sickness insurance instead of troublesome trade association and factory funds, ${ }^{(45)}$ or for more effective liability regulations instead of factory inspection, fell on deaf ears. It was the regulations of the Trade Code Amendment of 1883 that fulfilled the German-Austrian agreement of 1872 to establish obligatory sickness funds according to those existing in Prussia. $\stackrel{(46)}{ }$

The Iron Ring waited until Germany had enacted her sickness and accident insurance laws and used the popular appeal of this legislation to overcome resistance within its own ranks. Discussion about the matter began upon the initiative of Emil Steinbach, a bureaucrat then only in the middling level, who had started his career in the liberal era but adhered to the ideal of enlightened statecraft based upon corporative social

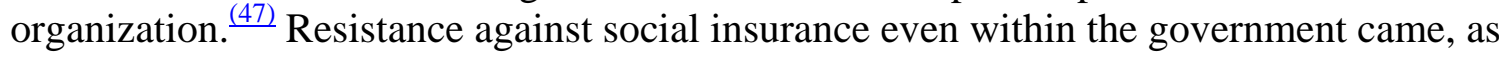
is shown by the debate of Steinbach's proposal in the Imperial Council of Ministers (Ministerrat), not only from the Minister of Agriculture, who advocated a reorganization following the pattern of miners' brotherhood chests, a traditional and highly paternalistic pattern. There also were fears that social insurance legislation did not really correspond to demands raised by the workers and would fail as a means of appeasement. The last point finally was a major motive for concentrating on accident insurance, because liability was a matter of public contention: in Austria it was still based with the exception of railways on individual causation of accidents by the employer exclusively. Moreover, provisions for sick workers were deemed to be settled already by the Trade Code of $1859 .{ }^{(48)}$

Accident insurance had a long and tiresome way to go before finally, in 1887, the law was enacted. ${ }^{(49)}$ It preceded sickness insurance, although its structure required a complementary sickness scheme. ${ }^{(50)}$ According to the Austrian and German laws, enterprises were insured against compensation claims from their workers for damages suffered in work-related accidents. For the first four (in Germany: thirteen) weeks after an accident that fully or partly incapacitated a worker to earn his living, he would have to rely on some sickness fund, his employer's help, or other expedients. After that, accident insurance came in, settling a temporary or permanent pension of not more than 60 percent (2/3 in Germany) of prior average earnings. It has to be kept in mind that, in exchange, workers were deprived of their right to sue their employers according to liability law.

Insurance was financed by contributions not only as in Germany from employers (90 percent) but from workers (10 percent) also, which was thought as an incentive for prudence as well as attachment, and as a visible legitimation for granting labor representation on the administrative boards. Again differing from Germany the accident insurance was based on a level premium procedure without state subsidies a system that reflected Austria's dire situation of state finance but caused grave financial difficulties for the accident insurance. 
The most characteristic points in which the Austrian law diverged from its German counterpart can be traced back to the Iron Ring's ideological preferences and particularly Austrian political constraints. Firstly, accident insurance in Austria, as it became effective in 1889, was tailored to large industry even more than Germany's by excluding not only (most) farms but also a much wider range of smaller plants and, most significantly, mines. ${ }^{(51)}$ All three groups figured as strongholds for traditionalism and represented crucial lobbies for the stability of the regime. In 1883, for example, the Minister of Agriculture, whose department also was in charge of the affairs of mining, threatened to blast the government if mines were included in the law. Nevertheless, the bill presented to the Emperor included the mining industry but was rejected by the Emperor himself for the same reason. $\stackrel{(52)}{ }$

The second outstanding characteristic of Austrian accident insurance was its administrative structure. There was notable hesitation as to this question in the early stages of planning both in Germany and in Austria. While Germany moved from a territorial organization towards one based on professional associations (Berufsgenossenschaften) with the Imperial Insurance Office as a center, Austrian politicians quickly moved in the opposite direction. Against fierce opposition from Liberals, German Nationalists, and employers' lobbies, the Iron Ring pushed through territorial institutions (Unfallversicherungsanstalten) comprising one or more crownlands, which were supervised by a department within the Ministry of the Interior itself. Self-administration thus was less marked in the Austrian than in the German case; instead, it favored a state centered and highly bureaucratized system, while the organization along regional lines clearly was a concession to federalistic options. ${ }^{(53)}$

The sickness insurance law of 1888 like in Germany caused fewer difficulties; again, its overall appearance looked very similar to Germany's scheme. Like Germany, Austria incorporated certain existing kinds of funds into the new system, so long as they complied with minimum requirements fixed by the law. Unlike the German sickness funds, the Austrian ones formed a network of sickness funds at the district level, not the municipal level (Bezirks- instead of Gemeindekrankenkassen). Apart from the fact that the scale of industrialization in Austria made a pervading system of local funds unpractical, the tying of funds to the political unit of districts meant more direct state interference. District authorities were notoriously prone to listen to local lobbies, but their

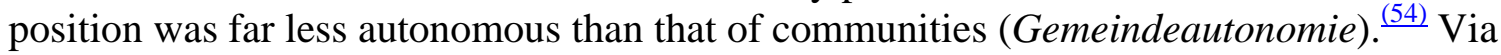
the accident insurance institutions (Unfallversicherungsanstalten), these district funds were also more directly connected to central state authorities. Another difference is that the Austrian law from the start incorporated free association funds (Vereinskassen) into the system, among which the most important were run by or in close connection to the Social Democratic labor movement. In Germany, the free association funds were regarded as alternative funds (Ersatzkassen), which were bound by the same requirements but could be used by the workers to avoid the compulsory system. In some sense then, the Iron Ring achieved what Bismarck had not been able to wrench from Liberals in the Reichstag. $\stackrel{(55)}{ }$ 
Besides the district and free association funds, the Austrian system also comprised factory and trade association funds which roughly correspond to the German Betriebskrankenkassen and both the Orts- and Innungskrankenkassen respectively, although in Austria all of them had their predecessors introduced by earlier laws. Finally, the law planned the erection of special funds for workers temporarily employed at large construction projects. Compulsory sickness insurance included all workers and white collar employees in industry, trade, commerce, and transportation with an income of not more than 1200 guilders a year. Miners were also included, but the special regulations applying to them were made subject of a separate law of 1889, which grossly demonstrated the conservative weight of mining interests. $\stackrel{(56)}{ }$

Sickness insurance paid minimum benefits amounting to 60 percent (Germany: 50 percent) of "customary local daily wages" for twenty (Germany: thirteen) weeks of sickness and four weeks of childbed. These "customary local daily wages" were fixed by the district authorities, who in most cases differentiated between supervisory, skilled, unskilled, male, female, and young workers. All insurance funds were also obliged to reimburse their members for medical treatment, drugs, and hospital care, and pay a lump sum for the burial of a deceased insured worker to his relatives. As a rule, workers financed two thirds, employers one third of the funds. Free association funds, however, often received no, or rather defied employers' contributions because representation of the two groups on the funds' administrative boards corresponded to their share in financing.

The Austrian sickness insurance law was comparatively broad-minded in its benefits, which, after all, were paid for by the workers themselves primarily. Accident insurance, on the other hand, was rather tight-fisted. Here, employers paid the major share, and although Austria had no state contributions, the danger that the need for subsidies would occur was much more imminent there than in the case of sickness insurance. The fear of a financial engagement most notably also prevented old age and invalidity insurance in Austria, which Bismarck had considered to be the core of his labor politics. Old age insurance was established for white collar employees in Austria in 1906 only in another effort to fight Social Democracy..$^{(57)}$ Old age insurance for workers was finally introduced in Austria after the Anschluss to Nazi Germany in 1938.

While constraints by the situation of state finance on the Iron Ring's social politics are quite obvious, it may be less clear to what extent the Iron Ring had regard for the industries' concerns. In the case of social insurance, it may be argued that the majority of employers had had to bear some costs for sick and injured workers before, that labor itself bore a great share, and that Austrian employers did not suffer a drawback at least vis-à-vis their most important, German competitors. It can be shown, I think, that despite their anti-capitalist ideology, Catholic reformers were highly conscious of the "needs" of Austrian industry also when they resolved on labor protection.

I have argued above that the compromises made during the negotiations about the bill already adapted the protective measures to standards that at the time prevailed in industry. It remains to have a look at the exceptions. The most important "exceptions" to 
standard working conditions in Austria appear to have occurred in the textile industry. Overly long hours were frequent there, as was female night work; and approximately half of the textile workforce were women. ${ }^{(58)}$ In fact, textile manufacturers were among those who preferred a general limitation of working hours to special protection for women only. The paramount thing for Gustav Pacher von Theinburg, a prominent Liberal M.P. and a textile manufacturer himself, was that "the female worker entered and left the workshop at the same time as the male worker" for otherwise women whose task was to assist their male co-workers would be worthless for the employer. In order to preserve cheap female labor, he put up with "a reasonable general limitation of working hours."

Many of the exceptions that the law made possible, which had in part been present in Belcredi's draft, had conditions in the textile industry in mind. Following passage of the Workers' Code in 1885, for example, the Ministry of Commerce hastily issued decrees that permitted night work by women and young girls, above all in several branches of the textile industry. ${ }^{(60)}$ And there are more subtle forms of preserving cheap female labor for all industries. In the negotiations about the "normal workday" the Iron Ring voted in favor of exempting preparatory and clearing work. In doing so, Austrian politicians explicitly referred to Swiss legislation, but they bashfully passed over the fact that the Swiss Factory Act of 1877 excluded married women not only young people from the respective clause. $\frac{(61)}{}$

A concluding assessment of conservative social politics In Austria in the 1880s could be that the combination of interests in the Iron Ring was the basis for embracing a wide range of policies that responded to the various "anti-sentiments" within it. The economically depressed Mittelstand and agrarians were relieved when labor protection concerned industrial enterprises only; social insurance appealed to anti-liberals of the Bismarckian mold; social insurance could be used also to promote federalism of a kind that did not immediately threaten the centralistic structure of the state. Both policies were considered useful in fighting Marxism and in strengthening the workers' loyalty to the Catholic monarchy. Anti-capitalism, however, and anti-industrialism, which were major rhetorical tools, remained tame in practice. Leading politicians in Austria were as aware as Bismarck that they would be ill advised to slaughter the cow that gave the milk not only to the workers but to the state as well. ${ }^{(62)}$

\section{Endnotes}

1. For an overview of factory and social insurance legislation in Austria of this period, see Emmerich Talos, Staatliche Sozialpolitik in Oesterreich. Rekonstruktion und Analyse (in Oesterreichische Texte zur Gesellschaftskritik 5, Vienna 1981), pp. 41-84.

2. Bundesgesetz betreffend die Arbeit in den Fabriken vom 23. Maerz 1877. The law is customarily referred to as "Fabrikgesetz 1877." 
3. See Erich Gruner, Die Arbeiter in der Schweiz im 19. Jahrhundert. Soziale Lage, Organisation, Verhaeltnis zu Arbeitgeber und Staat (in Helvetia Politica A, III, Bern 1968), especially pp. 227-252.

4. See e.g. Florian Tennstedt, Vom Proleten zum Industriearbeiter. Arbeiterbewegung und Sozialpolitik in Deutschland 1800 bis 1914 (in Schriftenreihe der Otto-BrennerStiftung 32, Cologne 1983) pp. 364-365. Hans Rothfels, Theodor Lohmann und die Kampfjahre der staatlichen Sozialpolitik (1871-1905) (Berlin 1927).

5. See Andreas Maurer, "Entstehung und Entwicklung der Sozialversicherung im schweizerischen Bundesstaat." In: Peter A. Koehler, Hans F. Zacher, eds., Beitraege zu Geschichte und aktueller Situation der Sozialversichung. Colloquium des Max-PlanckInstituts fuer auslaendisches und internationales Sozialrecht (in Schriftenreihe fuer Internationales und Vergleichendes Sozialrecht 8, Berlin 1983) pp. 780-787.

6. See Maurer, p. 782.

7. See Tennstedt, p. 365.

8. See William A. Jenks, Austria under the Iron Ring, 1879-1893 (Charlottesville 1965), and Hans Rosenberg, Grosse Depression und Bismarckzeit. Wirtschaftsablauf, Gesellschaft und Politik in Mitteleuropa (in Veroeffentlichungen der Historischen Kommission zu Berlin, Berlin 1967), pp. 227-52; especially p. 245.

9. Austria also had her anti-socialist laws; see Jenks, pp. 158-178.

10. An exception to this rule was Galicia, reflecting the compromise German Liberals had to make in 1867 with the Polish oligarchy of this crownland in exchange for strengthening their (constitutional) position vis-à-vis other "federalisms," notably the Czechs.

11. Ultimately, in 1893, the Taaffe government fell over the nationality question which here is seen as a problem of the structure of the Habsburg Empire. See Hugo Hantsch, Die Nationalitaetenfrage im alten Oesterreich. Das Problem der konstruktiven Reichsgestaltung (in Wiener Historische Studien 1, Vienna 1953) especially pp. 57-63. (Attempt at a Bohemian Ausgleich in 1890; earlier also abortive attempt at an Ausgleich with the Czechs during the short conservative interlude of the Hohenwart-Schaeffle government 1870/71. Successful Ausgleich attempts in the cases of Moravia, Galicia, and Bukovina came only 15 years later.)

12. See Karl Ucakar, Demokratie und Wahlrecht in Oesterreich. Zur Entwicklung von politischer Partizipation und staatlicher Legitimationspolitik (in Oesterreichische Texte zur Gesellschafts-kritik 24, Vienna 1985).

13. The rise of the share of agriculture is mainly due to a change of methods. It shows, however, that no dramatic change at the expense of agriculture had taken place. 
14. See Kurt Ebert, Die Anfaenge der modernen Sozialpolitik in Oesterreich. Die Taaffesche Sozialgesetzgebung fuer die Arbeiter im Rahmen der Gewerbeordnungsreform (1879-1885) (in Studien zur Geschichte der OesterreichischUngarischen Monarchie 15, Vienna 1975), p. 178. The author of the statement cannot be verified, as the files of the Ministerrat (Imperial Council of Ministers) were severely damaged in the fire of the Justizpalast in Vienna, July 15, 1927.

15. See Hugo Herz, Der gegenwaertige Stand und die Wirksamkeit der Arbeiterschutzgesetzgebung in Oesterreich (Leipzig/Vienna 1898), p. 6.

16. See Ebert, pp. 102-103.

17. Josef Weidenholzer, Der sorgende Staat. Zur Entwicklung der Sozialpolitik von Joseph II. bis Ferdinand Hanusch (Vienna/Munich/Zurich 1985), p. 107.

18. See Ludwig von Mises, "Zur Geschichte der oesterreichischen Fabrikgesetzgebung." In: Zeitschrift fuer Volkswirtschaft, Sozialpolitik und Verwaltung 14 (1905) pp. 209-271.

19. See Kaiserliches Patent ("Gewerbeordnung," Trade Code), December 20, 1859, RGBl. Nr. 227, section 84, lit. a).

20. Bureaucrats and law experts were aware that regulations of this traditional kind were void; see Allgemeines Verwaltungsarchiv, Justizministerium, Post 17, Z. 15599, December 12, 1872; see also Handausgabe der oesterreichischen Gesetze und Verordnungen, vol. 78, ed. Franz Mueller and Hugo Diwald (Vienna 1903), pp. 422-23; Viktor Mataja, Grundriß des Gewerberechts und der Arbeiterversicherung (in Grundriss des oesterreichischen Rechts in systematischer Bearbeitung 3/5, Leipzig 1899), pp. 6566; and Stefan Licht, Der gewerbliche Arbeitsvertrag in der Rechtsdurchsetzung (Brno 1898), pp. 46-47.

21. See Ebert, pp. 53-57.

22. See Ebert, p. 21. Giskra is said to have expressed the opinion that "[i]n Austria there is no social question, for us the social question stops at Bodenbach!" after listening to petitioning workers in 1868. Bodenbach (Podmokly) is a town in northern Bohemia at the border of Saxony.

23. Ernst von Plener, Die englische Fabriksgesetzgebung (Vienna 1871), pp. v-vi. This book was translated into English in 1873 as presumably the "first complete history of English Factory Legislation"! See Ernst von Plener, The English Factory Legislation: From 1802 till the Present Time (London 1873), quotation p. v (Introduction by Anthony John Mundella). The Austrian Ministry of Commerce itself published "the exemplary English laws" in German translation; see Die Fabriksgesetze Englands seit 1833. In deutscher Uebersetzung herausgegeben auf Veranlassung des k.k. Handelsministeriums (Vienna 1869), quotation on p. v. 
24. See my paper "Special Labor Protection for Women in Austria, 1860-1918" forthcoming in a volume edited by Alice Kessler-Harris, Jane Lewis, and Ulla Wikander.

25. Ernst von Plener's personal position on this question is not completely clear because he seems to advocate a general reduction of hours in the introduction to his report of 1871 on English factory legislation. As his subject was English legislation, which started by protecting women only, and because in the Parliamentary debates he always stood for special protection

for women, one may argue that this limitation was a matter of course. See, e.g., his Erinnerungen, vol. 2: Parlamentarische Taetigkeit 1873-1891 (Stuttgart/Leipzig 1921), p. 240.

26. See Allgemeines Verwaltungsarchiv, Justizministerium, Post 11, Z. 107, January 4, 1870 (note by the Minister of Commerce, Ignaz von Plener, December 28, 1869, Z. 25531). The comment is printed in Ludwig Bruegel, Soziale Gesetzgebung in Oesterreich von 1848 bis 1918. Eine geschichtliche Darstellung (Vienna/Leipzig 1919), pp. 70-77, the quotation on p. 75. Advocates of special protection for women themselves found it difficult to tackle the unequivocal legal situation in this point. This is demonstrated by the tricks they felt compelled to employ in order to separate adult women from the notion of "free agency" (Eigenberechtigung). See "Report of the Parliamentary Committee," No. CCVIII, Abgeordnetenhaus 1869. Quoted in ibid., p. 121.

27. See Ebert, pp. 28-29; Vogelsang's journal was the "Oesterreichische Monatsschrift fuer [Gesellschaftswissenschaft und] christliche Sozialreform."

28. See Margarete Grandner, "Staatliche Sozialpolitik in Cisleithanien 1867-1918." In: Helmut Rumpler, ed., Innere Staatsbildung und gesellschaftliche Modernisierung in Oesterreich und Deutschland 1867/71 bis 1914. Historikergespraech OesterreichBundesrepublik Deutschland 1989 (Vienna/Munich 1991), pp. 152-153; and Talos, pp. 43-46.

29. See Anon., "Die Frauenarbeit als Gegenstand der Fabrikgesetzgebung. Von einem Sachverstaendigen." In: Jahrbuch fuer Gesetzgebung, Verwaltung und Volkswirthschaft im Deutschen Reich N.F. 9 (1885), pp. 455-473, especially p. 461.

30. See No. 596 der Beilagen zu den Stenographisches Protokoll ueber die Sitzungen des Abgeordnetenhauses, IXth session, vol. 7 (December 5, 1882); and Klaus Berchtold (ed.), Oesterreichische Parteiprogramme 1868-1966 (Vienna 1967), p. 202 (the "Linz Program," especially item 26).

31. See Ebert, pp. 138-161. Amendment to the Trade Code, March 15, 1883, RGBl. No. 39. (Gesetz vom 15. Maerz 1883, RGBl. Nr. 39, betreffend die Abaenderung und Ergaenzung der Gewerbeordnung.) 
32. See Ebert, pp. 169, 174-175.

33. See Ebert, pp. 98-102.

34. See e.g. Ebert, p. 174. Critics of this regulation in Parliament were Liberals!

35. See Ebert, p. 172 (especially the statement by M.P. Heinrich Reschauer).

36. It is worth mentioning that the House of Deputies voted on the Factory Inspection Bill (March 12, 1883) before Count Egbert Belcredi presented his draft for a factory law to the Parliamentary Trade Committee (April 9, 1883). The Upper House of Parliament (Herrenhaus, House of Lords) accepted the bill on May 18, 1883. See Ebert, pp. 162 (note 1), 175-176.

37. See Gesetz vom 17. Juni 1885, RGBl. No. 117, betreffend die Bestellung von Gewerbeinspectoren; and Ebert pp. 162-175.

38. See Ebert, pp. 176-177.

39. See Ebert, pp. 185-186. Ebert credits this action to Leon Bilinski, one of the leading Polish politicians of the Iron Ring. I consider it to be highly improbable that Bilinski acted on his own in re-introducing the pattern of the factory bills of the 1870s, which all had distinguished between larger and smaller enterprises and which Belcredi appears to have disregarded on purpose. The line of procedure as suggested by Bilinski at the commencement of negotiations in my opinion served as a signal to the opposition that the Iron Ring was prepared to compromise.

40. See Gesetz vom 21. Juni 1884, RGBl. Nr. 115, betreffend die Beschaeftigung jugendlicher Arbeiter und Frauenspersonen, dann ueber die taegliche Dauer der Arbeit und die Sonntagsruhe im Bergbau; and Gesetz vom 8. Maerz 1885, RGBl. Nr. 22, betreffend die Abaenderung und Ergaenzung der Gewerbeordnung. Breaks and time for descent in mines were fixed at two hours according to the customary organization. Breaks in industry and trade had to amount to at least one-and-a-quarter hours, normally oneand-a-half hours. In few of the workshops workers were present longer than that, and there were special exceptions for continuous production (shorter breaks).

41. It is worth mentioning that by that time the opinion that women are not free agents, which had caused some difficulty for the reform-minded Liberals in the late 1860s (see footnote 27, above) now went without contradiction. The official report (Motivenbericht) of the Parliamentary Trade Committee (Gewerbeausschuss des Abgeordnetenhauses) about the bill claimed that "[i]n most civilized countries the realization of the necessity and the duty of the state to grant that protection [i.e. a restriction of working hours] at least to young workers and women has called forth legislative measures, while the same necessity to protect also adults (!) unfortunately has been tacitly acknowledged but not expressed in law in Europe with the exception of Switzerland." See No. 917 der Beilagen 
zu den Stenographischen Protokollen ueber die Sitzungen des Abgeordnetenhauses, IXth session, p. 3.

42. See Ebert, p. 187, and footnote 44. The German Trade Code of 1878 had a maternity leave of three weeks.

43. Gesetz vom 8. Maerz 1885, RGBI. Nr. 22, betreffend die Abaenderung und Ergaenzung der Gewerbeordnung. Technically, the "Workers' Code" ("Arbeiterordnung" was the term by which it was addressed at the time) figured as the (amended) VIIth part of the 1859 Trade Code.

44. See Hofmeister, "Landesbericht Oesterreich." In: Koehler, Zacher, p. 517.

45. It is worth noting at this point that Austria had no law like the German Hilfskassengesetz (1876) lending state support to autonomous insurance funds. A similar law was introduced in Austria only after the establishment of state sickness insurance in 1892. See Detlev Zoellner, "Landesbericht Deutschland." In: Koehler, Zacher, p. 81 and Hofmeister, pp. 573-577.

46. See Zoellner, p. 84.

47. See Hofmeister, pp. 518-520. Steinbach became Minister of Finance in 1891 and played a crucial role in the abortive effort of the Taaffe government to stabilize its dwindling support by the introduction of universal, fairly equal male suffrage in 1893 .

48. See Ebert, pp. 536-537.

49. See Gesetz vom 28. Dezember 1887, RGBI. No. 1 ex 1888, betreffend die Unfallversicherung der Arbeiter.

50. German legislators decided to postpone the accident insurance law until they had resolved the issue of sickness insurance. See Zoellner, p. 89 and Handwoerterbuch der Staatswissenschaften, vol. 7 (Jena 1926), p. 624. Hofmeister, pp. 548-549, doubts this interpretation. In the "Austrian solution," the accident insurance law of 1887 authorized the Minister of the Interior to determine the date the law would take effect; thus, sickness insurance came into existence before accident insurance. See ibid., p. 558 including footnotes 348 and 349.

51. See Hofmeister, p. 555.

52. See Hofmeister, pp. 542, 544-545 (including footnote 299). There were several extensions of accident insurance after the fall of the Iron Ring up to World War I including extraordinarily dangerous trades and state employees, most notably railway workers. The introduction of accident insurance for miners came only in 1914, and then by means of an Imperial Decree. 
53. Until the end of the Habsburg Monarchy Unfallversicherungsanstalten existed (from east to west) in Lemberg [Lwow, Lwiw] for Galicia and Bukovina; in Bruenn [Brno] for Moravia and Silesia; in Vienna for Lower Austria, in Graz for Styria and Carinthia; in Prague [Praha] for Bohemia; in Triest [Trieste, Trst] for Carniola, Dalmatia and the Triest area; in Salzburg for Upper Austria, Salzburg, Tyrol and Vorarlberg.

54. See Jiri Klabouch, "Die Lokalverwaltung in Cisleithanien." In: Adam Wandsruszka, Peter Urbanitsch, eds., Die Habsburgermonarchie 1848-1918, vol.II: Verwaltung und Rechtswesen (Vienna 1975), pp. 270-305.

55. See Tennstedt, p. 334.

56. See Gesetz vom 28. Juli 1889, $R G B l$. Nr. 127 ; the law had to be amended already in 1891 because it did not work at all. See Gesetz vom 30. Dezember 1891, RGBl. Nr. 3 ex 1892.

57. See Gesetz vom 16. Oktober 1906, RGBl. Nr. 1 ex 1907, betreffend die Pensionsversicherung der in privaten Diensten und einiger in oeffentlichen Diensten Angestellten. The law came before the first election based on the universal, equal male suffrage took place. See Talos, p. 117; Germany appears to have copied this example; see Gerhard A. Ritter, Social Welfare in Germany and Britain: Origins and Development (Leamington Spa/New York 1983), p. 93.

58. Census data and numbers mentioned by contemporaries vary. See e.g. Birgit Bolognese-Leuchtenmueller, Bevoelkerungsentwicklung und Berufsstruktur, Gesundheits- und Fuersorgewesen in Oesterreich 1750-1918 (in Materialien zur Wirtschafts- und Sozialgeschichte 1, Vienna 1978), part II, pp. 166-173; and Stenographische Protokolle ueber die Sitzungen des Hauses der Abgeordneten, IXth session, vol. 12, p. 12873 (Leon Ritter von Bilinski).

59. See Gustav von Pacher, Zur Reform der Fabriksgesetzgebung in Oesterreich (Vienna 1884) pp. 49-50. See also Stenographische Protokolle ueber die Sitzungen des Abgeordnetenhauses, IXth session, vol. 12, p. 12845 (the liberal economist Emil Sax). In 1868, 15 out of the 29 Chambers of Commerce in Austria had not opposed a general standardization of working time although at a higher level. See Gutachten der Handelsund Gewerbekammern ueber die

Regelung der Arbeitszeit in Fabriken. Herausgegeben auf Veranlassung des k.k. Handelsministeriums (Vienna 1869).

60. See Decrees, May 27, 1885, RGBl. Nos. 84 to 86. For the lobbies demanding exceptions from the prohibition of female night work see, e.g., the petition by the Silesian Chamber of Commerce, May 13, 1885, in: Stenographische Protokolle ueber die Sitzungen des Hauses der Abgeordneten, IXth session, vol. 12, pp. 12891-94, esp. p. 12893. 
61. See Ebert, pp. 39 and 214. The Liberal M.P. Dr. Johann Freiherr von Chlumetzky, former Minister of Commerce, justified his motion with the argument that this clause had been taken over "almost verbally" from the Swiss Factory Act (section 12). There was no contradiction.

62. Bismarck's comparisons of industry with cows and hens are notorious. See e.g. Otto von Bismarck, Die gesammelten Werke, vol.12: Reden 1878-1885. Bearbeitet von Wilhelm Schuessler (Berlin 1929), pp. 318, 438. 